\title{
FAKTOR-FAKTOR YANG BERHUBUNGAN DENGAN KESIAPSIAGAAN KELUARGA DALAM MENGHADAPI BENCANA DI KOTA PALANGKA RAYA
}

\author{
${ }^{1}$ Supriandi* \\ ${ }^{1}$ Poltekkes Kemenkes Palangka Raya \\ ${ }^{1}$ Uzanksupriandi80@yahoo.com*
}

\begin{abstract}
Abstrak
Latar Belakang : Bencana merupakan peristiwa atau rangkaian peristiwa yang mengancam dan mengganggu kehidupan dan penghidupan masyarakat yang disebabkan oleh faktor alam dan/atau faktor non-alam maupun faktor manusia, sehingga mengakibatkan timbulnya korban jiwa manusia, dan dampak psikologis. Tujuan : Penelitian ini adalah untuk mengetahui faktor-faktor yang berhubungan dengan kesiapsiagaan keluarga dalam menghadapi bencana di kota Palangka Raya.

Metode : Jenis penelitian ini menggunakan desain deskriptif analitik dengan pendekatan Cross sectional study. Penelitian ini dilakukan di empat kelurahan di Kota Palangka Raya yang terdiri dari kelurahan Pahandut Seberang, Marang, Bereng Bengkel dan Petuk ketimpun.

Hasil : Faktor-faktor yang berhubungan dengan kesiapsiagaan keluarga dalam menghadapi bencana dengan nilai signifikan 0,05 adalah pengetahuan responden dengan nilai $P_{\text {value }}=0,049$ yang artinya $P_{\text {value }} \leq 0,05$, kemudian sikap responden dengan nilai $\mathrm{P}_{\text {value }}=0,043$ yang artinya $\mathrm{P}_{\text {value }} \leq 0,05$ dan terakhir ada dukungan anggota keluarga dengan nilai value $P_{\text {value }}=0,028$ yang artinya $P_{\text {value }} \leq 0,05$.
\end{abstract}

Simpulan : Ada hubungan antara pengetahuan, sikap dan dukungan keluarga terhadap kesiapsiagaan menghadapi bencana.

Kata Kunci : Kesiapsiagaan; Bencana; Pengetahuan; Sikap; Dukungan

\section{FACTORS RELATED TO FAMILY PREPAREDNESS OF DEALING WITH DISASTERS IN PALANGKA RAYA}

\begin{abstract}
Background: Disasters are events or series of events that threaten and disrupt people's lives and livelihoods caused by natural factors and / or non-natural factors as well as human factors, resulting in human casualties and psychological impacts.

The Purpose: This study is to determine the factors associated with family preparedness in facing disasters in the city of Palangka Raya.

Method: This research uses an analytic descriptive design with a cross sectional study approach. This research was conducted in four villages in Palangka Raya City consisting of Pahandut Seberang, Marang, Bereng Bengkel and Petuk kelimpun.

Results: Factors related to family preparedness in facing disasters with a significant value of 0.05 were respondents' knowledge with a value of Pvalue $=$ 0.049 which means Pvalue $\leq 0.05$, then the attitude of respondents with a value of
\end{abstract}


Pvalue $=0.043$ which means $P$ value $\leq 0,05$ and finally there is the support of family members with a value of $P$ value $=0.028$, which means $P$ value $\leq 0.05$.

Conclusion: There is a relationship between knowledge, attitudes and family support for disaster preparedness.

Keywords: Preparedness; Disaster; Knowledge; Attitude; Support

\section{PENDAHULUAN}

Bencana merupakan peristiwa atau rangkaian peristiwa yang mengancam dan mengganggu kehidupan dan penghidupan masyarakat yang disebabkan oleh faktor alam dan/atau faktor non-alam maupun faktor manusia, sehingga mengakibatkan timbulnya korban jiwa manusia, dan dampak psikologis. Bencana akibat ulah manusia muncul karena tidak adanya kearifan dalam memanfaatkan lingkungan, antara lain banjir, longsor, kekeringan, kebakaran hutan dan polusi serta kegagalan teknologi lainnya. (Kodoatie RJ dkk, 2010)

Indonesia menempati urutan ketiga di dunia sebagai negara yang paling rawan dan paling sering dilanda bencana banjir, setelah India dan China (BNPB 2012). Beberapa penelitian di Indonesia menunjukan masih lemahnya upaya kesiapsiagaan dan penanganan darurat untuk menghadapi bencana secara mandiri dan proaktif. Hal ini tergambar dari studi kesiapsiagaan warga dalam menghadapi bencana di beberapa daerah dengan menilai indeks kesiapsiagaan dilihat dari sisi individu dan keluarga, komunitas sekolah dan pemerintah yang masih rendah dengan kategori kurang siap (Nugroho, 2015).

Bencana akibat ulah manusia muncul karena tidak adanya kearifan dalam memanfaatkan lingkungan, antara lain banjir, longsor, kekeringan, kebakaran hutan dan polusi serta kegagalan teknologi lainnya, seperti kasus Lumpur Lapindo, kebocoran pabrik nuklir.( BNPB 2012).

Penguatan kesiapsiagaan bencana merupakan prioritas utama dari program manajemen bencana pemerintah di tingkat Nasional maupun daerah (United Nations International Strategy for Disaster Reduction (UNISDR), 2014 \& United States Agency for International Development (USAID), 2013). Namun pemerintah mempunyai keterbatasan waktu dan mobilitas bantuan kepada masyarakat. Oleh karena itu, perencanaan kesiapsiagaan yang didasarkan pada tanggung jawab individu dan keluarga menjadi sorotan utama untuk diperbaiki (Tomio et al., 2014).

Beberapa penelitian di Indonesia menunjukan masih lemahnya upaya kesiapsiagaan dan penanganan darurat untuk menghadapi bencana secara mandiri dan proaktif. Hal ini tergambar dari studi kesiapsiagaan warga dalam menghadapi bencana di beberapa daerah dengan menilai indeks kesiapsiagaan dilihat dari sisi individu dan keluarga, komunitas sekolah dan pemerintah yang masih rendah dengan kategori kurang siap (Nugroho, 2015).

Berdasarkan studi pendahuluan pada BPBD Kota Palangka Raya, permasalahan yang ada di Kota Palangka Raya adalah minimnya pengetahuan untuk memulai gerakan siaga bencana. Dari latar belakang diatas maka peniliti tertarik untuk melakukan penelitian di masyarakat khususnya Kota Palangka Raya dengan judul "Faktor-Faktor Yang Berhubungan Dengan Kesiapsiagaan Keluarga 
Dalam Menghadapi Bencana Di kota Palangka Raya" dengan tujuan dapat menganalisis faktor-faktor yang berhubungan dengan kesiapsiagaan keluarga dalam menghadapi bencana.

\section{METODE}

Penelitian ini menggunakan desain deskriptif analitik dengan pendekatan Cross sectional study. Dengan menggunakan systematik random sampling. Penelitian ini dilaksanakan di empat Kelurahan pada empat kecamatan yang berada di wilayah kawasan rawan bencana dengan kategori tinggi di wilayah Kecamatan Jekan Raya kelurahan Petuk Ketimpun, Kelurahan Pahandut Seberang Kecamataan Pahandut, kelurahan Bereng Bengkel Kecamatan Sebangau, dan Desa Marang Kecamatan Bukit Batu. Populasi pada penilitian ini adalah keluarga yang beresiko tinggi terdampak bencana sebanyak 100 orang. Teknik pengambilan sampel yang digunakan adalah dengan systematik random sampling.

Penelitian ini dilakukan di 4 (empat) Kecamatan dan 4 (empat) kelurahan di kota Palangka Raya, waktu penelitian bulan April - Oktober 2019. Teknik pengolahan data yang terdiri dari :

1. Entry data adalah proses memasukan data dari kuesioner ke dalam program komputer dengan menggunakan SPSS setelah seluruh kuesioner melalui tahap editing dan coding.

2. Transformation yaitu menjumlahkan data-data sesuai dengan variabel masingmasing untuk mendapatkan skor. Setelah itu dari setiap skor-skor variabel tersebut kemudian di transformasi ke dalam beberapa kelompok berdasarkan nilai skor dari masing-masing variabel.

3. Cleaning yaitu pengecekan ulang data-data yang sudah di entry untuk memeriksa adanya kesalahan.

Kemudian untuk uji instrumen dengan teknik analisa data yaitu :

1. Analisis univariat, untuk mendeskripsikan masing-masing variabel bebas atau terikat.

2. Analisis bivariat, hubungan antara variabel independen dengan variabel dependen. Uji yang digunakan adalah uji Chi-Square $\left(\mathrm{X}^{2}\right)$ yang digunakan untuk melihat hubungan variabel kategorik dengan variabel kategorik. Jika $P_{\text {value }} \leq 0,05$ maka berarti ada hubungan yang bermakna secara statistik dan jika nilai $\mathrm{P}_{\text {value }}>0,05$ maka berarti tidak ada hubungan yang bermakna secara statistik. (Hastono, 2010) .

\section{Analisa Univariat}

\section{HASIL DAN PEMBAHASAN}

Tabel 1. Distribusi Frekuensi Karakteristik Usia Responden Hasil Analisis Univariat Berdasarkan Karakteristik Responden

\begin{tabular}{ccc}
\hline Usia & Frekuensi $(\mathbf{N})$ & Persentase $(\boldsymbol{\%})$ \\
\hline 15-25 Tahun & 12 Orang & 12,0 \\
26-30 Tahun & 35 Orang & 35,0 \\
36-45 Tahun & 30 Orang & 30,0 \\
46-55 Tahun & 18 Orang & 18,0 \\
56-65 Tahun & 3 Orang & 3,0
\end{tabular}




$\begin{array}{ccc}66-75 \text { Tahun } & 2 \text { Orang } & 2,0 \\ \text { Total } & 100 \text { Orang } & 100\end{array}$

Berdasarkan Tabel 1 diatas dapat diketahui responden terbanyak terdapat pada usia 26-20 tahun dengan 35 responden (35,0\%). Usia tidak sepenuhnya menjadi faktor utama pembentukan kesiapsiagaan keluarga. Terdapat faktorfaktor lain untuk membentuk kesiapsiagaan keluarga seperti pengalaman. Responden dengan usia lebih tua namun tidak memiliki pengalaman menghadapi bencana akan memiliki kesiapsiagaan yang kurang bila dibandingkan dengan usia lebih muda yang berdomisili di daerah rawan bencana.

Tabel 2. Distribusi Frekuensi Karakteristik Jenis Kelamin Responden

\begin{tabular}{ccc}
\hline Jenis Kelamin & Frekuensi (n) & Persentase (\%) \\
\hline Laki-laki & 68 & 68,0 \\
Perempuan & 32 & 32,0 \\
Total & 100 Orang & 100 \\
\hline
\end{tabular}

Beradasarkan Tabel 2 diatas diketahui responden terbanyak adalah lakilaki dengan 68 responden $(68,0 \%)$. Jenis kelamin tidak menjadi faktor utama terhadap kesiapsagaan keluarga menghadapi bencana. Hal ini disebabkan karena pengaruh faktor lain seperti pengetahuan yang dimiliki individu serta pengalaman individu mengalami bencana.

Tabel 3. Distribusi Frekuensi Karakteristik Pendidikan Responden

\begin{tabular}{ccc}
\hline Pendidikan & Frekuensi (n) & Persentase (\%) \\
\hline SD & 44 & 44,0 \\
SMP & 29 & 29,0 \\
SLTA & 21 & 21,0 \\
Perguruan Tinggi & 6 & 6,0 \\
Total & 100 Orang & 100 \\
\hline
\end{tabular}

Berdasarkan Tabel 3 diatas didapatkan pendidikan responden terbanyak yaitu SD dengan 44 responden $(44,0 \%)$. Pendidikan tidak sepenuhnya mempengaruhi perilaku kesiapsiagaan keluarga. Faktor pengalaman dan pengetahuan menjadi faktor lain yang mempengaruhi perilaku kesiapsiagaan keluarga.

Tabel 4. Distribusi Frekuensi Karakteristik Pekerjaan Responden

\begin{tabular}{ccc}
\hline Pekerjaan & Frekuensi (n) & Persentase (\%) \\
\hline Tidak Bekerja & 10 & 10,0 \\
Pedagang & 16 & 16,0 \\
Buruh/Tukang & 16 & 16,0 \\
PNS/TNI/Polri & 6 & 6,0 \\
Ibu Rumah Tangga & 22 & 22,0 \\
Nelayan & 30 & 30,0 \\
Total & 100 Orang & 100 \\
\hline
\end{tabular}


Berdasarkan Tabel 4 diatas didapatkan responden terbanyak dengan pekerjaan sebagai nelayan sebanyak 30 responden $(30,0 \%)$. Pekerjaan responden yang mayoritas sebagai nelayan memiliki dampak positif khusus karena seorang nelayan memiliki pengalaman melalui aktivitas sehari-harinya.

Tabel 5. Distribusi Frekuensi Karakteristk Penghasilan Responden

\begin{tabular}{ccc}
\hline Penghasilan & Frekuensi (n) & Persentase (\%) \\
\hline <Rp 1.000.000 & 74 & 74,0 \\
Rp 1.000.000 - Rp 3.000.000 & 20 & 20,0 \\
$>$ Rp 3.000.000 & 6 & 6,0 \\
Total & 100 Orang & 100 \\
\hline
\end{tabular}

Berdasarkan Tabel 5 diatas diketahui responden dengan penghasilan $<\mathrm{Rp} 1.000 .000$ sebanyak 74 orang $(74,0 \%)$. . Penghasilan yang rendah dapat mengakibatkan tingkat pendidikan yang rendah namun, penghasilan tidak menjadi tolok ukur kesiapsiagaan bencana masyarakat hal ini disebabkan karena faktor lain seperti pengalaman.

Tabel 6. Distribusi Frekuensi Karakteristik Responden Dalam Mengikuti Komunitas Bencana

\begin{tabular}{ccc}
\hline Mengikuti Komunitas Bencana & Frekuensi (n) & Persentase (\%) \\
\hline Ya & 12 & 12,0 \\
Tidak & 88 & 88,0 \\
Total & 100 Orang & 100 \\
\hline
\end{tabular}

Berdasarkan Tabel 6 diatas didapatkan hasil responden yang mengikuti komunitas bencana adalah sebanyak 88 responden tidak pernah mengikuti komunitas bencana $(88,0 \%)$. Kurangnya partisipasi masyarakat dalam komunitas bencana disebabkan oleh pengalaman masyarakat sehingga masyarakat menganggap komunitas itu tidak diperlukan karena mereka dapat memahami sendiri kondisi lingkungan sekitar tempat tinggalnya.

Tabel 7. Distribusi Frekuensi Karakteristik Responden Dalam Mengikuti Pelatihan Bencana

\begin{tabular}{ccc}
\hline Mengikuti Pelatihan Bencana & Frekuensi (n) & Persentase (\%) \\
\hline Pernah & 8 & 8,0 \\
Tidak Pernah & 92 & 92,0 \\
Total & 100 Orang & 100 \\
\hline
\end{tabular}

Berdasarkan Tabel 7 diatas didapatkan hasil sebanyak 92 responden tidak pernah mengikuti pelatihan bencana $(92,0 \%)$. Pelatihan atau training adalah salah satu bentuk proses pendidikan untuk memfasilitasi peserta agar memperoleh pengalaman-pengalaman belajar yang akhirnya akan menimbulkan perubahan perilaku mereka (Notoatmodjo, 2007).

Tabel 8. Distribusi Frekuensi Pegetahuan Responden

\begin{tabular}{ccc}
\hline Pengetahuan & Frekuensi (n) & Presentase (\%) \\
\hline Baik & 90 & 90,0
\end{tabular}




$\begin{array}{ccc}\text { Cukup } & 10 & 10,0 \\ \text { Kurang } & 0 & 0 \\ \text { Total } & 100 \text { Orang } & 100\end{array}$

Berdasarkan hasil analisis diatas didapatkan pengetahuan baik sebanyak 88 responden $(88,0 \%)$. Pengetahuan yang dimiliki biasanya dapat mempengaruhi sikap dan kepedulian masyarakat untuk siap dan siaga dalam mengantisipasi bencana terutama bagi mereka yang bertempat tinggal di daerah rawan bencana seperti banjir. Faktor yang mempengaruhi pengetahuan yaitu faktor internal dan eksternal.

Tabel 9. Distribusi Frekuensi Sikap Responden

\begin{tabular}{ccc}
\hline Sikap & Frekuensi (n) & Presentase (\%) \\
\hline Baik & 97 & 97,0 \\
Cukup & 3 & 3,0 \\
Kurang & 0 & 0 \\
Total & 100 Orang & 100 \\
\hline
\end{tabular}

Berdasarkan tabel 9 diatas didapatkan hasil sikap responden adalah baik sebanyak 97 responden (97,0\%). Sikap secara realitas menunjukkan adanya kesesuaian respons terhadap stimulus tertentu (Sunaryo, 2004). Responden pada penelitian ini memiliki sikap dan pengetahuan yang baik terhadap seluruh aspek kegiatan kesiapsiagaan bencana.

Tabel 10. Distribusi Frekuensi dukungan keluarga

\begin{tabular}{ccc}
\hline Dukungan Keluarga & Frekuensi (n) & Presentase (\%) \\
\hline Baik & 46 & 46,0 \\
Cukup & 44 & 44,0 \\
Kurang & 10 & 10,0 \\
Total & 100 Orang & 100 \\
\hline
\end{tabular}

Berdasarkan tabel diatas diketahui responden dengan dukungan keluarga sebanyak 46 responden (46,0\%). Menurut Friedman (1998) keluarga merupakan sebuah sumber pertolongan praktis dan kongkrit yang mencakup dukungan atau bantuan seperti uang, peralatan, waktu, serta modifikasi lingkungan. Ini termasuk dalam jenis dukungan instrumental yang bertujuan untuk meringankan beban bagi individu sehingga keluarga dapat memenuhinya.

\section{Analisa Bivariat}

Tabel 11. Hubungan Usia Responden dengan Kesiapsiagaan Keluarga Menghadapi Bencana di Kota Palangka Raya

\begin{tabular}{|c|c|c|c|}
\hline \multirow{3}{*}{ Usia } & Kesiapsiagaan Keluarga & \multirow{3}{*}{ Tot } & \multirow{3}{*}{$P$ value } \\
\hline & $\mathbf{K u}$ & & \\
\hline & $\mathbf{f}$ & & \\
\hline
\end{tabular}




\begin{tabular}{ccccccc}
\hline 15-25 Tahun & 0 & $0,0 \%$ & 12 & $12,0 \%$ & 12 & \\
26-30 Tahun & 3 & $3,0 \%$ & 32 & $32,0 \%$ & 35 & \\
36-45 Tahun & 1 & $1,0 \%$ & 29 & $29,0 \%$ & 30 & \\
46-55 Tahun & 2 & $2,0 \%$ & 16 & $16,0 \%$ & 18 & 0,745 \\
56-65 Tahun & 0 & $0,0 \%$ & 3 & $3,0 \%$ & 3 & \\
66-75 Tahun & 0 & $0,0 \%$ & 2 & $2,0 \%$ & 2 & \\
Jumlah & 6 & $6,0 \%$ & 94 & $94 \%$ & 100 & \\
\hline
\end{tabular}

Berdasarkan tabel 11 diketahui hasil uji chi-square dengan taraf signifikan 5\% $(0,05)$ diperoleh bahwa $P_{\text {value }}=0,745$ yang berarti $P_{\text {value }}>0,05$ maka tidak ada hubungan yang bermakna antara usia responden dengan kesiapsiagaan keluarga dalam menghadapi bencana banjir di Kota Palangka Raya.

Tabel 12. Hubungan Jenis Kelamin Responden dengan Kesiapsiagaan Keluarga Menghadapi Bencana di Kota Palangka Raya

\begin{tabular}{|c|c|c|c|c|c|c|c|}
\hline \multirow{3}{*}{ Jenis Kelamin } & \multicolumn{4}{|c|}{ Kesiapsiagaan Keluarga } & \multirow{3}{*}{ Total } & \multirow{3}{*}{ P value } & \multirow{3}{*}{$\begin{array}{l}\text { Odds Ratio } \\
\text { (OR) }\end{array}$} \\
\hline & \multicolumn{2}{|c|}{ Kurang Siap } & \multicolumn{2}{|c|}{ Siap } & & & \\
\hline & $\mathbf{f}$ & $\%$ & $\mathbf{F}$ & $\%$ & & & \\
\hline Perempuan & 2 & $2,0 \%$ & 30 & $30,0 \%$ & 32 & & \\
\hline Laki-laki & 4 & $4,0 \%$ & 64 & $64,0 \%$ & 68 & 0,942 & 1,067 \\
\hline Jumlah & 6 & $6,0 \%$ & 94 & $94,0 \%$ & 100 & & \\
\hline
\end{tabular}

Berdasarkan tabel 12 diketahui hasil uji chi-square dengan taraf signifikan 5\% $(0,05)$ diperoleh bahwa $\mathrm{P}_{\text {value }}=0,942$ yang berarti $\mathrm{P}_{\text {value }}>0,05$ maka tidak ada hubungan yang bermakna antara jenis kelamin responden dengan kesiapsiagaan keluarga dalam menghadapi bencana banjir di Kota Palangka Raya.Selain itu diperoleh nilai Odds Ratio $(\mathrm{OR})=1,067$ yang berarti Odds Ratio (OR)>1 maka jenis kelamin sebagai faktor risiko terhadap kesiapsiagaan keluarga dalam menghadapi bencana banjir di Kota Palangka Raya.

Tabel 13. Hubungan Pendidikan Responden dengan Kesiapsiagaan Keluarga Menghadapi Bencana di Kota Palangka Raya

\begin{tabular}{|c|c|c|c|c|c|c|}
\hline \multirow{3}{*}{ Pendidikan } & \multicolumn{4}{|c|}{ Kesiapsiagaan Keluarga } & \multirow{3}{*}{ Total } & \multirow{3}{*}{ Pvalue } \\
\hline & \multicolumn{3}{|c|}{ Kurang Siap } & \multirow{2}{*}{$\frac{\text { Siap }}{\%}$} & & \\
\hline & $\mathbf{f}$ & $\%$ & $\mathbf{F}$ & & & \\
\hline $\mathrm{SD}$ & 5 & $5,0 \%$ & 39 & $39,0 \%$ & 12 & \multirow{5}{*}{0,209} \\
\hline SMP & 0 & $0,0 \%$ & 32 & $32,0 \%$ & 35 & \\
\hline SLTA & 1 & $1,0 \%$ & 29 & $29,0 \%$ & 30 & \\
\hline Perguruan Tinggi & 0 & $0,0 \%$ & 16 & $16,0 \%$ & 18 & \\
\hline Jumlah & 6 & $6,0 \%$ & 94 & $94 \%$ & 100 & \\
\hline
\end{tabular}

Berdasarkan tabel 13 diketahui hasil uji chi-square dengan taraf signifikan 5\% $(0,05)$ diperoleh bahwa $\mathrm{P}_{\text {value }}=0,209$ yang berarti $\mathrm{P}_{\text {value }}>0,05$ maka tidak ada hubungan yang bermakna antara pendidikanresponden dengan kesiapsiagaan keluarga dalam menghadapi bencana banjir di Kota Palangka Raya. 
Tabel 14. Hubungan Pekerjaan Responden dengan Kesiapsiagaan Keluarga Menghadapi Bencana di Kota Palangka Raya

\begin{tabular}{|c|c|c|c|c|c|c|}
\hline \multirow{3}{*}{ Pekerjaan } & \multicolumn{4}{|c|}{ Kesiapsiagaan Keluarga } & \multirow{3}{*}{ Total } & \multirow{3}{*}{ P value } \\
\hline & \multicolumn{2}{|c|}{ Kurang Siap } & \multicolumn{2}{|c|}{ Siap } & & \\
\hline & f & $\%$ & $\mathbf{F}$ & $\%$ & & \\
\hline Tidak Bekerja & 1 & $1,0 \%$ & 9 & $9,0 \%$ & 10 & \\
\hline Pedagang & 2 & $1,0 \%$ & 14 & $14,0 \%$ & 16 & \\
\hline Buruh/Tukang & 1 & $1,0 \%$ & 15 & $15,0 \%$ & 16 & \\
\hline PNS/TNI/Polri & 0 & $0,0 \%$ & 6 & $6,0 \%$ & 6 & 0,802 \\
\hline Ibu Rumah Tangga & 1 & $1,0 \%$ & 21 & $21,0 \%$ & 23 & \\
\hline Nelayan & 1 & $1,0 \%$ & 29 & $29,0 \%$ & 30 & \\
\hline Jumlah & 6 & $6,0 \%$ & 94 & $94 \%$ & 100 & \\
\hline
\end{tabular}

Berdasarkan tabel 14 diketahui hasil uji chi-square dengan taraf signifikan 5\% $(0,05)$ diperoleh bahwa $P_{\text {value }}=0,802$ yang berarti $P_{\text {value }}>0,05$ maka tidak ada hubungan yang bermakna antara pekerjaan responden dengan kesiapsiagaan keluarga dalam menghadapi bencana banjir di Kota Palangka Raya.

Tabel 15. Hubungan Penghasilan Responden dengan Kesiapsiagaan Keluarga Menghadapi Bencana di Kota Palangka Raya

\begin{tabular}{cccccccc}
\hline \multirow{2}{*}{ Penghasilan } & \multicolumn{3}{c}{ Kesiapsiagaan Keluarga } & \multirow{2}{*}{ Total } & \multirow{2}{*}{ P value } \\
\cline { 2 - 5 } & \multicolumn{2}{c}{ Kurang Siap } & \multicolumn{2}{c}{ Siap } & & & \\
\cline { 2 - 5 } & f & $6,0 \%$ & 68 & $68,0 \%$ & 74 & \\
\hline Rp 1.000.000 1.000.000 $-\operatorname{Rp~3.000.000~}$ & 6 & $0,0 \%$ & 20 & $64,0 \%$ & 20 & 0,329 \\
$>$ Rp 3.000.000 & 0 & $0,0 \%$ & 6 & $0,6 \%$ & 6 & \\
Jumlah & 6 & $6,0 \%$ & 94 & $94,0 \%$ & 100 & \\
\hline
\end{tabular}

Berdasarkan tabel 15 diketahui hasil uji chi-square dengan taraf signifikan 5\% $(0,05)$ diperoleh bahwa $\mathrm{P}_{\text {value }}=0,329$ yang berarti $\mathrm{P}_{\text {value }}>0,05$ maka tidak ada hubungan yang bermakna antara penghasilan responden dengan kesiapsiagaan keluarga dalam menghadapi bencana banjir di Kota Palangka Raya.

Tabel 16. Hubungan Mengikuti Komunitas Bencana dengan Kesiapsiagaan Keluarga Menghadapi Bencana di Kota Palangka Raya

\begin{tabular}{|c|c|c|c|c|c|c|c|}
\hline \multirow{3}{*}{$\begin{array}{c}\text { Mengikuti } \\
\text { Komunitas } \\
\text { Bencana }\end{array}$} & \multicolumn{4}{|c|}{ Kesiapsiagaan Keluarga } & \multirow{3}{*}{ Total } & \multirow{3}{*}{$\begin{array}{c}P \\
\text { value }\end{array}$} & \multirow{3}{*}{$\begin{array}{l}\text { Odds } \\
\text { Ratio } \\
\text { (OR) }\end{array}$} \\
\hline & \multicolumn{2}{|c|}{ Kurang Siap } & \multicolumn{2}{|c|}{ Siap } & & & \\
\hline & $\mathbf{f}$ & $\%$ & $\mathbf{F}$ & $\%$ & & & \\
\hline $\mathrm{Ya}$ & 1 & $1,0 \%$ & 11 & $11,0 \%$ & 12 & & \\
\hline Tidak & 5 & $5,0 \%$ & 83 & $83,0 \%$ & 88 & 0,717 & 1,509 \\
\hline Jumlah & 6 & $6,0 \%$ & 94 & $94,0 \%$ & 100 & & \\
\hline
\end{tabular}

Berdasarkan tabel 16 diketahui hasil uji chi-square dengan taraf signifikan 5\% $(0,05)$ diperoleh bahwa $P_{\text {value }}=0,717$ yang berarti $P_{\text {value }}>0,05$ maka tidak ada hubungan yang bermakna antara mengikuti komunitas bencana dengan kesiapsiagaan keluarga dalam menghadapi bencana banjir di Kota 
Palangka Raya. Selain itu diperoleh nilai Odds Ratio $(\mathrm{OR})=1,509$ yang berarti Odds Ratio (OR)>1 maka mengikuti komunitas bencana sebagai faktor risiko terhadap kesiapsiagaan keluarga dalam menghadapi bencana banjir di Kota Palangka Raya.

Tabel 17. Hubungan Mengikuti Pelatihan Bencana dengan Kesiapsiagaan Keluarga Menghadapi Bencana di Kota Palangka Raya

\begin{tabular}{|c|c|c|c|c|c|c|c|}
\hline \multirow{3}{*}{ Pelatihan Bencana } & \multicolumn{4}{|c|}{ Kesiapsiagaan Keluarga } & \multirow{3}{*}{ Total } & \multirow{3}{*}{$\begin{array}{c}P \\
\text { value }\end{array}$} & \multirow{3}{*}{$\begin{array}{l}\text { Odds Ratic } \\
\quad \text { (OR) }\end{array}$} \\
\hline & \multicolumn{2}{|c|}{ Kurang Siap } & \multicolumn{2}{|c|}{ Siap } & & & \\
\hline & $\mathbf{f}$ & $\%$ & $\mathbf{F}$ & $\%$ & & & \\
\hline Pernah & 1 & $1,0 \%$ & 7 & $7,0 \%$ & 8 & & \\
\hline Tidak Pernah & 5 & $5,0 \%$ & 87 & $87,0 \%$ & 92 & 0,420 & 2,486 \\
\hline Jumlah & 6 & $6,0 \%$ & 94 & $94,0 \%$ & 100 & & \\
\hline
\end{tabular}

Berdasarkan tabel 17 diketahui hasil uji chi-square dengan taraf signifikan 5\% $(0,05)$ diperoleh bahwa $\mathrm{P}_{\text {value }}=0,420$ yang berarti $\mathrm{P}_{\text {value }}>0,05$ maka tidak ada hubungan yang bermakna antara pelatihan responden dengan kesiapsiagaan keluarga dalam menghadapi bencana banjir di Kota Palangka Raya. Selain itu diperoleh nilai Odds Ratio $(\mathrm{OR})=2,486$ yang berarti Odds Ratio (OR) $>1$ maka pelatihan bencana sebagai faktor risiko terhadap kesiapsiagaan keluarga dalam menghadapi bencana banjir di Kota Palangka Raya.

Tabel 18. Hubungan Pengetahuan Responden dengan Kesiapsiagaan Keluarga Menghadapi Bencana di Kota Palangka Raya

\begin{tabular}{|c|c|c|c|c|c|c|c|}
\hline \multirow{3}{*}{ Pengetahuan } & \multicolumn{4}{|c|}{ Kesiapsiagaan Keluarga } & \multirow{3}{*}{ Total } & \multirow{3}{*}{$\begin{array}{c}P \\
\text { value }\end{array}$} & \multirow{3}{*}{$\begin{array}{l}\text { Odds Ratio } \\
\text { (OR) }\end{array}$} \\
\hline & \multicolumn{2}{|c|}{ Kurang Siap } & \multicolumn{2}{|c|}{ Siap } & & & \\
\hline & $\mathbf{F}$ & $\%$ & $\mathbf{F}$ & $\%$ & & & \\
\hline Kurang & 0 & $0,0 \%$ & 0 & $0,0 \%$ & 0 & & \\
\hline Cukup & 2 & $2,0 \%$ & 8 & $8,0 \%$ & 10 & 0040 & 5.275 \\
\hline Baik & 4 & $4,0 \%$ & 86 & $86,0 \%$ & 68 & 0,049 & $5,5 / 5$ \\
\hline Jumlah & 6 & $6,0 \%$ & 94 & $94,0 \%$ & 100 & & \\
\hline
\end{tabular}

Berdasarkan tabel 18 diketahui hasil uji chi-square dengan taraf signifikan 5\% $(0,05)$ diperoleh bahwa $\mathrm{P}_{\text {value }}=0,049$ yang berarti $\mathrm{P}_{\text {value }} \leq 0,05$ maka ada hubungan yang bermakna antara pengetahuan responden dengan kesiapsiagaan keluarga dalam menghadapi bencana banjir di Kota Palangka Raya. Selain itu diperoleh nilai Odds Ratio $(\mathrm{OR})=5,375$ yang berarti Odds Ratio $(\mathrm{OR})>1$ maka pengetahuan sebagai faktor risiko terhadap kesiapsiagaan keluarga dalam menghadapi bencana banjir di Kota Palangka Raya.

Tabel 19. Hubungan Sikap Responden dengan Kesiapsiagaan Keluarga Menghadapi Bencana di Kota Palangka Raya

\begin{tabular}{|c|c|c|c|c|c|c|c|}
\hline \multirow{3}{*}{ Sikap } & \multicolumn{4}{|c|}{ Kesiapsiagaan Keluarga } & \multirow{3}{*}{ Total } & \multirow{3}{*}{ P value } & \multirow{3}{*}{$\begin{array}{l}\text { Odds Ratio } \\
\quad \text { (OR) }\end{array}$} \\
\hline & \multicolumn{2}{|c|}{ Kurang Siap } & \multicolumn{2}{|c|}{ Siap } & & & \\
\hline & $\mathbf{F}$ & $\%$ & $\mathbf{F}$ & $\%$ & & & \\
\hline Kurang & 0 & $0,0 \%$ & 0 & $0,0 \%$ & 0 & & \\
\hline Cukup & 1 & $1,0 \%$ & 2 & $2,0 \%$ & 3 & 0,043 & 9,200 \\
\hline Baik & 5 & $5,0 \%$ & 92 & $92,0 \%$ & 97 & & \\
\hline
\end{tabular}




$\begin{array}{llllll}\text { Jumlah } & 6 & 6,0 \% & 94 & 94,0 \% & 100\end{array}$

Berdasarkan tabel 19 diketahui hasil uji chi-square dengan taraf signifikan 5\% $(0,05)$ diperoleh bahwa $\mathrm{P}_{\text {value }}=0,043$ yang berarti $\mathrm{P}_{\text {value }} \leq 0,05$ maka ada hubungan yang bermakna antara sikap responden dengan kesiapsiagaan keluarga dalam menghadapi bencana banjir di Kota Palangka Raya. Selain itu diperoleh nilai Odds Ratio $(\mathrm{OR})=9,200$ yang berarti Odds Ratio (OR)>1 maka sikap sebagai faktor risiko terhadap kesiapsiagaan keluarga dalam menghadapi bencana banjir di Kota Palangka Raya.

Tabel 20. Hubungan Dukungan Anggota Keluarga dengan Kesiapsiagaan Keluarga Menghadapi Bencana di Kota Palangka Raya

\begin{tabular}{|c|c|c|c|c|c|c|}
\hline \multirow{3}{*}{ Dukungan } & \multicolumn{4}{|c|}{ Kesiapsiagaan Keluarga } & \multirow{3}{*}{ Total } & \multirow{3}{*}{$\begin{array}{c}P \\
\text { value }\end{array}$} \\
\hline & \multicolumn{2}{|c|}{ Kurang Siap } & \multicolumn{2}{|c|}{ Siap } & & \\
\hline & $\mathbf{f}$ & $\%$ & $\mathbf{F}$ & $\%$ & & \\
\hline Kurang & 2 & $2,0 \%$ & 8 & $8,0 \%$ & 10 & \\
\hline Cukup & 4 & $4,0 \%$ & 40 & $40,0 \%$ & 44 & \\
\hline Baik & 0 & $0,0 \%$ & 46 & $46,0 \%$ & 46 & $0,0<8$ \\
\hline Jumlah & 6 & $6,0 \%$ & 94 & $94,0 \%$ & 100 & \\
\hline
\end{tabular}

Berdasarkan tabel 20 diketahui hasil uji chi-square dengan taraf signifikan 5\% (0,05) diperoleh bahwa $\mathrm{P}_{\text {value }}=0,028$ yang berarti $\mathrm{P}_{\text {value }} \leq 0,05$ maka ada hubungan yang bermakna antara dukungan anggota keluarga dengan kesiapsiagaan keluarga dalam menghadapi bencana banjir di Kota Palangka Raya.

Berdasarkan tabel 11 data hasil penelitian usia responden di dominasi pada kategori usia produktif yaitu antara 26-35 tahun sebanyak 35 orang (35\%) dan usia dewasa akhir 36-45 tahun sebanyak 30 orang (30\%). Sedangkan presentase paling rendah ada pada kelompok usia 56-65 tahun sebanyak 3 orang (3\%) dan usia 66-75 tahun sebanyak 2 orang (2\%). Hasil penelitian ini sejalan dengan penelitian Novian Andri Akhirianto (2018) dimana responden penelitian berada di usia produktif (antara 25-29 tahun) sebanyak 10,79\% dari total penduduk, sedangkan penduduk pada kelompok umur 60-64 tahun memiliki persentase paling rendah, yaitu hanya 1,65 persen. Kondisi tersebut merupakan hal yang baik, karena kerentanan dari faktor umur penduduk termasuk rendah. Hasil analisis chi-square $\mathrm{P}_{\text {value }}=0,745$ artinya tidak ada hubungan bermakna antara usia dengan kesiapsiagaan menghadapi bencana. Hasil ini sejalan dengan penelitian Asih Dwi Hayu Pangesti (2012) yang menyimpulkan tidak ada hubungan antara usia responden dengan tingkat pengetahuan tentang kesiapan bencana dengan nilai $\mathrm{P}_{\text {value }}=0,875$.

Tabel 12 menujukkan bahwa karakteristik jenis kelamin responden penelitian ini sabanyak $68 \%$ berjenis kelamin laki-laki, data ini masih sesuai dengan data dari Palangka.go.id pada tahun 2015 yang menyatakan bahwa jumlah penduduk Kota Palangka Raya lebih didominasi oleh laki-laki. Hasil penelitian ini tidak sejalan dengan penelitian Novian Andri Akhirianto (2018) dimana responden penelitian didominasi oleh perempuan $(61,67 \%)$ disebabkan karena waktu yang digunakan pada saat penyebaran kuesioner adalah pada hari dan jam kerja. 
Tabel 13, Pendidikan responden pada penelitian ini didominasi dengan tingkat pendidikan SD sebanyak 44 orang (44\%). Pada umumnya makin tinggi pendidikan seseorang makin mudah menerima informasi. Hasil analisis chi-square $\mathrm{P}_{\text {value }}=0,209$ artinya tidak ada hubungan yang bermakna antara pendidikanresponden dengan kesiapsiagaan keluarga dalam menghadapi bencana. Pendidikan tidak sepenuhnya mempengaruhi perilaku kesiapsiagaan keluarga. Faktor pengalaman dan pengetahuan menjadi faktor lain yang mempengaruhi perilaku kesiapsiagaan keluarga.

Tabel 14, pekerjaan responden didominasi sebagai nelayan sebanyak 30 orang $(30 \%)$. Hasil analisis chi-square $\mathrm{P}_{\text {value }}=0,802$ artinya tidak ada hubungan yang bermakna antara pekerjaan responden dengan kesiapsiagaan keluarga dalam menghadapi bencana.

Tabel 15, Penghasilan responden penelitian didominasi $<1.000 .000$ sebanyak 74 orang $(74 \%)$. Hasil analisis chi-square $\mathrm{P}_{\text {value }}=0,329$ artinya tidak ada hubungan yang bermakna antara penghasilan responden dengan kesiapsiagaan keluarga dalam menghadapi bencana. Penghasilan yang rendah dapat mengakibatkan tingkat pendidikan yang rendah namun, penghasilan tidak menjadi tolok ukur kesiapsiagaan bencana masyarakat hal ini disebabkan karena faktor lain seperti pengalaman.

Tabel 16, Keikutsertaan responden dalam komunitas bencana sangat minim yaitu sebanyak 12 orang (12\%) dan sisanya sebanyak 88 orang $(88 \%)$ tidak mengikuti komunitas bencana. Hasil analisis chi-square $\mathrm{P}_{\text {value }}=0,717$ artinya tidak ada hubungan yang bermakna antara mengikuti komunitas bencana dengan kesiapsiagaan keluarga dalam menghadapi bencana. Selain itu diperoleh nilai Odds Ratio $(\mathrm{OR})=1,509$ artinya mengikuti komunitas bencana sebagai faktor risiko terhadap kesiapsiagaan keluarga dalam menghadapi bencana.

Tabel 17, Pelatihan penanggulangan bencana sebanyak 92 orang $(92 \%)$ responden tidak pernah mengikutinya. Hasil analisis chi-square $P_{\text {value }}=0,420$ artinya tidak ada hubungan yang bermakna antara pelatihan responden dengan kesiapsiagaan keluarga dalam menghadapi bencana. Selain itu diperoleh nilai Odds Ratio $(\mathrm{OR})=2,486$ artinya pelatihan bencana sebagai faktor risiko terhadap kesiapsiagaan keluarga dalam menghadapi bencana.

Tabel 18, Berdasarkan data hasil penelitian pengetahuan responden $90 \%$ baik. Hasil uji chi-square $\mathrm{P}_{\text {value }}=0,049$ artinya ada hubungan yang bermakna antara pengetahuan responden dengan kesiapsiagaan keluarga dalam menghadapi bencana. Selain itu diperoleh nilai Odds Ratio $(\mathrm{OR})=5,375$ artinya pengetahuan sebagai faktor risiko terhadap kesiapsiagaan keluarga dalam menghadapi bencana. Pengetahuan yang dimiliki biasanya dapat mempengaruhi sikap dan kepedulian masyarakat untuk siap dan siaga dalam mengantisipasi bencana terutama bagi mereka yang bertempat tinggal di daerah rawan bencana seperti banjir.

Tabel 19, Berdasarkan data penelitian menunjukkan 97\% responden memiliki sikap baik dalam kesiapsiagaan bencana. Hasil analisi chi-square $\mathrm{P}_{\text {value }}=$ 0,043 artinya ada hubungan yang bermakna antara sikap responden dengan kesiapsiagaan keluarga dalam menghadapi bencana. Selain itu diperoleh nilai Odds Ratio $(\mathrm{OR})=9,200$ artinya sikap sebagai faktor risiko terhadap kesiapsiagaan keluarga dalam menghadapi bencana. 
Tabel 20, Berdasarkan data penelitian menunjukkan $46 \%$ responden memiliki dukungan keluarga yang baik dan $44 \%$ responden memiliki dukungan keluarga yang cukup namun masih ada 10 responden yang memiliki dukungan keluarga kurang. Hasil analisis chi-square $\mathrm{P}_{\text {value }}=0,028$ artinya ada hubungan yang bermakna antara dukungan anggota keluarga dengan kesiapsiagaan keluarga dalam menghadapi bencana.

Hasil analisis bivariat didapatkan tiga variabel yang memiliki hubungan denngan kesiapsiagaan keluarga dalam menghadapi bencana di Kota Palangka Raya dengan nilai signifikan 5\% $(0,05)$. Pertama, hubungan pengetahuan responden dengan kesiapsiagaan keluarga dalam menghadapi bencana dengan nilai $\mathrm{P}_{\text {value }}=0,049$ maka $\mathrm{P}_{\text {value }} \leq 0,05$ yang artinya terdapat hubungan antara pengetahuan dengan kesiapsiagaan keluarga dalam menghadapi bencana. Kedua, hubungan sikap dengan kesiapsiagaan dalam menghadapi bencana dengan nilai $\mathrm{P}_{\text {value }}=0,043$ yang berarti $\mathrm{P}_{\text {value }} \leq 0,05$ yang artinya terdapat hubungan antara sikap dengan kesiapsiagaan keluarga dalam menghadapi bencana. sikap sebagai faktor risiko terhadap kesiapsiagaan keluarga dalam menghadapi bencana. Ketiga, hubungan dukungan keluarga dalam menghadapi bencana dengan nilai $\mathrm{P}_{\text {value }}=$ 0,028 maka $P_{\text {value }} \leq 0,05$ yang artinya terdapat hubungan antara dukungan anggota keluarga dengan kesiapsiagaan dalam menghadapi bencana. Selain itu, pengetahuan dan sikap responden yang berada pada kategori baik berpengaruh pada dukungan anggota keluarga dalam mengantisipasi resiko bencana banjir.

Hasil penelitian ini tidak sejalan dengan penelitian Nurma Susilawati (2015) yang menunjukkan bahwa dukungan anggota keluarga termasuk dalam kategori sedang sebanyak 39 responden $(62,9 \%)$ yang disebabkan bahwa dalam keluarga kurang memperhatikan dan peduli mengenai persiapan dan peralatan yang diperlukan sebelum, saat dan setelah bencana bencana.

\section{SIMPULAN}

Berdasarkan hasil dari penelitian yang telah dilakukan di 4 kelurahan di Kota Palangka Raya dengan responden sebanyak 100 orang. Karakteristik persentase usia responden terbanyak adalah usia 26-30 tahun sebanyak 35 orang (35\%), persentase jenis kelamin responden terbanyak adalah laki-laki sebanyak 68 orang $(68 \%)$, persentase pendidikan responden terbanyak adalah tingkat SD sebanyak 30 orang $(30 \%)$, persentase penghasilan responden terbanyak adalah $<\operatorname{Rp} 1.000 .000$ sebanyak 74 orang (74\%), persentase komunitas bencana terbanyak adalah responden yang tidak mengikuti komunitas bencana sebanyak 88 orang $(88 \%)$, persentase pelatihan bencana terbanyak adalah responden yang tidak pernah mengikuti pelatihan bencana sebanyak 92 orang (92\%).

Pengetahuan responden dengan persentase sebanyak $90 \%$ dan diperoleh nilai $\mathrm{P}_{\text {value }}=0,049$ yang artinya ada hubungan antara pengetahuan responden dengan kesiapsiagaan keluarga dalam menghadapi bencana. Sikap responden dengan persentase sebanyak 97 orang adalah baik (97\%) dan diperoleh nilai $\mathrm{P}_{\text {value }}=0,043$ yang artinya ada hubungan antara sikap responden dengan kesiapsiagaan keluarga dalam menghadapi bencana. Dukungan responden dengan persentase sebanyak 46 responden (46\%) adalah baik dan diperoleh $\mathrm{P}_{\text {value }}$ 
$=0,028$ yang artinya adanya hubungan antara dukungan keluarga dengan kesiapsiagaan dalam menghadapi bencana.

\section{SARAN}

Responden dan masyarakat menjadikan hasil penelitian ini sebagai informasi untuk meningkatkan kesiapsiagaan keluarga dalam mengahadapi bencana banjir khususnya di Kota Palangka Raya. Diharapkan hasil penelitian ini dapat digunakan sebagai referensi dan informasi dasar untuk penelitian selanjutnya yang berkaitan dengan proses pembelajaran ilmu keperawatan manajemen bencana. Diharapkan di kota Palangka Raya, terutama di kelurahankelurahan yang rawan bencana banjir, dibentuk komunitas bencana sebagai wadah berkumpulnya warga untuk mendapatkan informasi-informasi terkait bencana yang ada di wilayahnya.

\section{DAFTAR PUSTAKA}

Asi Dwi Hayu Pangesti. 2012,'Gambaran Tingkat Pengetahuan dan Aplikasi Kesiapan Bencana Pada Mahasiswa Fakultas Ilmun Keperawatan Universitas Indonesia Tahun 2012

Badan Nasional Penanggulangan Bencana. Masterplan Pengurangan Risiko Bencana Tsunami: BNPB; 2012.

Kodoatie RJ, Sjarief R. Tata Ruang Air, Pengelolaan Bencana, Pengelolaan Infrastruktur, Penataan Ruang Wilayah dan Pengelolaan Lingkungan Hidup. Yogyakarta: ANDI; 2010.

Nugroho Preparedness Assessment Tools For Indonesia. Jakarta: Humanitarian Forum Indonesia \& MDM. Praktik dalam Keperawatan. Jakarta : Salemba 2015

Novian Andri Akhirianto. 2018,'Pengetahuan dan Kesiapsiagaan Masyarakat Terhadap Bencana Banjir di Kota Bekasi (Studi Kasus: Perumahan Pondok Gede Permai)'. [Online], dari: http://docplayer.info/98836939-Pengetahuandan-kesiapsiagaan-masyarakat-terhadap-bencana-banjir-di-kota-bekasistudi-kasus-perumahan-pondok-gede-permai.html [30 Oktober 2019].

Nurma Susilawati. 2015, 'Hubungan Pengetahuan dan Dukungan Anggota Keluarga Dengan Kesiapsiagaan Rumah Tangga Dalam Menghadapi Bencana Gempa Bumi Didusun Soronanggan Panjangrejp Pundong Bantul'[Online],dari:http://digilib.unisayogya.ac.id/133/1/NASKAH\%20PU BLIKASI.pdf [30 Oktober 2019].

Tomio, at al (2014). Household and Community Disaster Preparedness in Japanese Provincial City: A Population-Based Household Survey. Advances in Anthropology, 4:68-77; 2014

United Nations International Strategy for Disaster Reduction (UNISDR), 2014 \& United States Agency for International Development (USAID), 2013) $\&$ United Nations International Strategy for Disaster Reduction (UNSDR). 
(2014). Terminology on disaster risk reduction. Di akses tanggal 20 Januari 2019, dari http://www.unisdr.org/who-weare/what-is-drr 